\title{
Non-State Actors: Carving out a Space in a State-Centred International Legal System
}

\author{
Cedric Ryngaert ${ }^{1}$
}

Published online: 28 July 2016

(c) The Author(s) 2016. This article is published with open access at Springerlink.com

\begin{abstract}
States have captured the imagination of international legal scholars, to the extent that for a variety of non-state actors (NSAs), statehood may appear to be the ultimate prize. This contribution sheds some light on how the epistemic community has come to venerate the state as the structural embodiment of politico-legal order, as 'the hero' in international law narratives and how, nevertheless, NSAs have been allowed to carve out a space for themselves. It is argued that in spite of NSAs' gradual emancipation, to this very day, the presence of the state continues to loom large in discussions on international legal subjectivity.
\end{abstract}

Keywords Non-state actors · States · Law-making · Compliance-monitoring · Dispute-settlement · Obligations · Responsibility

\section{Introduction}

Philip Alston originally coined the 'not-a-cat' syndrome to describe how we look at non-state actors (NSAs): as being characterized by what they are not-namely states-rather than by what they are. ${ }^{1}$ States have indeed captured the imagination,

\footnotetext{
1 Alston (2005).

Cedric Ryngaert is a member of the Board of Editors of the Netherlands International Law Review. The author appreciates the financial support from the European Research Council (Proposal 336230UNIJURIS) and the Dutch Organization for Scientific Research (No. 016.135.322). This contribution is based on a keynote speech which the author delivered at the biennial meeting (theme: non-state actors) of the British Branch of the International Law Association at Lancaster University, 8 April 2016, and at a seminar on 'A State-Centred International Legal System', at Maastricht University, 27 May 2016.
}

Cedric Ryngaert

C.M.J.Ryngaert@uu.nl

1 Professor of Public International Law, Utrecht University, Utrecht, The Netherlands 
to the extent that for a variety of NSAs, statehood may appear to be the ultimate prize, the nec plus ultra of being taken seriously in the international community. ${ }^{2}$ In this short contribution, drawing on my experience as a rapporteur of the International Law Association's Committee on Non-State Actors (2008-2014), I shed some light on how our epistemic community has come to venerate the state as the structural embodiment of politico-legal order, as 'the hero' in international law narratives (Sect. 2) — and how, nevertheless, NSAs have been allowed to carve out a space for themselves (Sect. 3). Subsequently, I will give a bird's eye view of NSAs' extant rights (Sect. 4) and obligations (Sect. 5) under international law, i.e., the scope of their international legal personality. I will argue that in spite of NSAs' gradual emancipation, to this very day, the presence of the state-as the gatekeeper of the international legal system and the circle of relevant international legal subjects - continues to loom large in discussions on international legal subjectivity (Sect. 6). In this contribution, I focus in particular on organized non-state collectivities, such as non-governmental organizations, corporations, and armed groups. I pay only marginal attention to individuals and intergovernmental organizations.

\section{Monoglossia: The State as the Hero of International Law}

Hero worship is not unique to the law. It speaks to a deep human desire to identify one entity, or one person, as a saviour of sorts, who can cope with a variety of challenges and can serve as a role model for us all. Hero worship is at the basis of the major monotheist religions, and it has also informed the style of literature known as 'the epic'. The epic narrates the great achievements of one particular hero, such as Homer's Odysseus, and shuns the contribution of other protagonists. The epic of international law obviously casts the state as the hero and minimizes - at least in its traditional incarnation-the contributions of NSAs.

The epic was the dominant literary style in earlier times. However, it has been largely overtaken by 'the novel', a style in which a variety of characters, and not just one hero, play a role. Think, for instance, of Charles Dickens's acclaimed novel 'A Tale of Two Cities' (1859), set against the background of the French Revolution. ${ }^{3}$ This book has not one, but three main characters, a French aristocrat and a British lawyer who falls in love with the Frenchman's wife. While the Brit finally offers his own life instead of the Frenchman's on the gallows, the important takeaway is not that the Brit is the hero, but that a variety of protagonists enter the stage. This speaks to a reality of pluralism, with a number of rather different actors playing their part in the story.

In literary theory, it is to his credit that the Russian literary critic Mikhail Bakhtin examined these genres of the epic and the novel, using the terms 'monoglossia' and 'heteroglossia'-denoting respectively the one-person and multiple-person

\footnotetext{
${ }^{2}$ E.g., the armed group Daesh has formally proclaimed an Islamic State. See on the rise of this 'state': Cockburn (2015).

${ }^{3}$ Dickens (1859).
} 
narratives. ${ }^{4}$ Bakhtin has proved quite influential in semiotics, anthropology and communication studies. However, recently his work has also been discovered by scholars of law and governance, most notably by Mariana Valverde, a critical theorist of scale and temporality who recently published the Bakhtin-inspired Chronotopes of the Law. ${ }^{5}$ Valverde makes, inter alia, the point that the law, including international law, is a monoglossia centred around the state and that it is the task of the critical scholar to debunk myths of the state, and to find space for non-state counter-narratives, or heteroglossia.

Let us be honest, debunking myths and imagining new realities is not the forte of international lawyers steeped in the positivist tradition. We have been taught-and we teach-that international law is what states make of it. We meekly refer and defer to the list of sources of international law in Article 38 of the Statute of the International Court of Justice (ICJ) - which all put the state at the centre of attention. A critical scholar may however want to inquire why the state has cast such a spell, and whether there are, or should be, juridical openings for NSAs within the state system.

Historicizing the international legal system is a first step in this regard. We should remember that imagining the body politic along territorial, state lines is the result of a historically contingent confluence of a variety of material and epistemic factors in the early modern period. ${ }^{6}$ Medieval times indeed presented us with a heteroglossian social reality, with a variety of territorial and non-territorial actors exercising power. Kings vied for power with local lords, with the Pope and with cities whose merchants engaged in long-distance trade. Territorial, 'state' norms existed alongside non-state norms, such as the lex mercatoria, canon law or the legal practices of the guilds. Legal allegiances were not exclusive to the state but were overlapping. In the 16th century, however, the emergence of the science of cartography allowed secular rulers to draw more detailed boundaries, an event that entrenched the power of the state and of territorial law. Branch's (2013) narrative of this historic trail is well worth reading in this regard. ${ }^{7}$

For our purposes, it is crucial to understand that the state gradually crowded out non-state jurisdictional orders which could not easily be 'mapped' in the technical sense of the word. The year 1648 is typically cited as a key moment; the Peace of Westphalia, allegedly for the first time in history, defined the international community as a community of states, endowed with full external and internal sovereignty. This Peace did away with 'transnational' allegiances and incorporated rights and properties within the territorial jurisdiction and sovereignty of the state. ${ }^{8}$ The heyday of the state would then follow in the 19th century, when a movement emerged to channel nationalist sentiment through the territorial nation state.

\footnotetext{
${ }^{4}$ Bakhtin (1981).

5 Valverde (2015).

${ }^{6}$ E.g., Ruggie (1993).

7 Branch (2013). From a critical legal perspective: Ford (1999).

${ }^{8}$ E.g., Art. LXXVI of the Peace of Westphalia (incorporating within the Kingdom of France, "with all manner of Jurisdiction and Sovereignty', 'all the Rights, Regales and Appurtenances, without any reserve').
} 


\section{Heteroglossia: A Continuous Role for Non-State Actors in the International System}

While the state, with its monoglossian ambitions, has gradually entrenched its power and captured legal and political scholars' imagination, the reality of international life has actually been different. Even in our post-16th century Modern Age, NSAs have continued to play roles in international affairs. ${ }^{9}$ In the 17 th century, the East India Companies, while perhaps not fully operating independently from the state, wielded enormous private economic power, having the monopoly on overseas trade with the colonies. They can be considered as the precursors of the modern-day multinational corporations. ${ }^{10}$ In the late 18 th century, anti-slavery societies in the United Kingdom and the United States started to militate against the slave trade, eventually successfully. They can be considered as the first non-governmental organizations (NGOs). ${ }^{11}$ In the 19th and early 20th century, peace movements were instrumental in the establishment of arbitral tribunals and ultimately the League of Nations. ${ }^{12}$ At the same time, women's associations, attacking male-dominated state hierarchies, managed to empower women - admittedly an ongoing struggle. And the 19th century recognition of belligerency conferred a measure of legal personality on insurgents, thereby foreshadowing the current legal international humanitarian law status of nonstate armed groups in non-international armed conflicts.

The World Court has also played its part in this respect. While the Court (in its incarnations of the Permanent Court of International Justice (PCIJ) and the ICJ) is considered as a state-centred mechanism par excellence, it is recalled that its recognition of NSAs' legal status has not been marginal. In the 1928 Beamtenabkommen case, for instance, a case concerning the railway personnel of Danzig, the PCIJ held that 'the very object of an international agreement, according to the intention of the contracting Parties, may be the adoption by the Parties of some definite rules creating individual rights and enforceable by the national courts' ${ }^{13}$ In so doing, it confirmed that international law could create rights for individuals. Also, in two other cases involving Poland, Minority Schools and German Settlers, the PCIJ ruled that the object of a treaty (in the case the League of Nations' Minority Treaties) could be the protection of individual rights. ${ }^{14}$ Just after the Second World War, as is well known, the newly established ICJ issued the famous Reparation advisory opinion, in which it confirmed that there could be more subjects of international law than just states. ${ }^{15}$

\footnotetext{
${ }^{9}$ I limit myself here to a brief overview of the role of NSAs in the European history/tradition of international law, as European powers have arguably played a dominant role in the creation of modern international law. See for a critical discussion Orakhelashvili (2006).

${ }^{10}$ Robins (2012).

11 Martinez (2013).

${ }^{12}$ Charnovitz (1996), p. 193.

${ }^{13}$ PCIJ, Jurisdiction of the Courts of Danzig (The Beamtenabkommen), PCIJ Reports, Series B, No. 15.

${ }^{14}$ PCIJ, Minority Schools in Albania, Advisory Opinion, PCIJ Reports, Series A/B, No. 64; PCIJ, Questions relating to Settlers of German Origin in Poland, Advisory Opinion, PCIJ Reports, Series B, No. 6.

${ }^{15}$ ICJ, Reparation for Injuries Suffered in the Service of the United Nations, Advisory Opinion, ICJ Reports 1949, p. 174.
} 
While the case concerned international organizations, its dictum could just as well apply to other NSAs; they could be endowed with international legal personality insofar as this would satisfy the needs of the international community, at least as so perceived by states.

The term international legal person-although widely used in international law circles, especially after the Reparation opinion-has little analytical purchase in itself, however. It is not an a priori threshold that needs to be crossed before an NSA can enjoy rights or obligations under international law. Rather, an NSA enjoys international legal personality because it enjoys certain obligations. The focus of the inquiry should thus simply be on whether an international norm creates rights or obligations for an actor, and when this is indeed the case, the addressee of the norm can be considered as an international legal person. Thus, when we say that an NSA is a subject of international law, it simply means that it enjoys certain rights and/or obligations under international law.

This brief overview shows us that the international legal system, as also further developed by the World Court, has been more heteroglossian than meets the untrained eye. There are, and may be, other subjects of international law than only states, possessing international rights and obligations of a variable nature and scope. It remains, however, that such rights and obligations are almost exclusively created by states, albeit for NSAs. States thus remain the gatekeepers of the international legal system; they decide who is in and who is out. A fine example is Article 71 United Nations (UN) Economic and Social Council (ECOSOC) Committee which decides on the accreditation of NGOs with ECOSOC; this Committee is composed of only states - a state of affairs which surely deserves criticism. So after all, heteroglossia may be more imaginary than real. States, or states assembled in international organizations, are still pulling the strings, and arguably only accept NSAs insofar as these serve the purposes of the state or organization. As Kenneth Anderson has pointed out, the UN has accepted NGOs with open arms to shore up its own legitimacy (but as NGOs are lacking legitimacy themselves, this may come down to a lovers' embrace of death). ${ }^{16}$ States for their part have merrily supported NGOs which serve as force multipliers for the state's political agenda, with states sometimes setting up their own government-organized NGOs (GONGOs). ${ }^{17}$ And investors' rights under international law have only been enhanced because investors' home states have concluded bilateral investment treaties containing these very rights.

Small wonder, then, that some scholars have advocated taking heteroglossia seriously, by giving primary agency to all international actors. The New Haven School's characterization of international law, as a process of authoritative decision-making by a variety of interested actors rather than as a set of rigid rules, is the most well known in this respect. ${ }^{18}$ This School does away with a formal notion of international legal subjectivity and emphasizes how actors materially participate in the creation of rules considered as authoritative although perhaps not

\footnotetext{
16 Anderson (2010).

17 Cumming (2010).

18 Lasswell and McDougal (1992).
} 
necessarily binding in an Article 38 ICJ Statute sense. ${ }^{19}$ Philip Jessup's Transnational Law also fits this mould; it collapses the distinction between the public and the private and gives legal agency to all transnationally active actors. ${ }^{20}$

These truly heteroglossian approaches, while influential in critical scholarship, have nevertheless failed to enter the mainstream. That being said, what is undeniable is that a panoply of actors play in role in global governance. The term global governance itself has even been invented to denote governance beyond the state: governance by, or at least including, NSAs. ${ }^{21}$ What this means for legal normativity is another question, however. We turn to this question in the next section.

\section{The Role of Non-State Actors in Contemporary International Law- Making, Compliance-Monitoring, and Dispute-Settlement}

Most international lawyers with a positivist bent would not deny the important role played by NSAs in the functioning of the current international legal system, but they consider their impact on law-making, compliance-monitoring, and dispute-settlement largely as the outcome of a two-level game. ${ }^{22}$ This means that NSAs do not have a direct impact on international law-creation but they are free to influence the actual law-making agencies: states. Law-applying agencies will normally not take issue with how state or organizational authoritative decision-making has come into being. A rare counter-example is ICJ Judges Guillaume and Oda's criticism of the UN General Assembly resolution requesting the ICJ to give an advisory opinion on the use of nuclear weapons in 1996, on the ground that NGOs were behind this resolution. ${ }^{23}$ However, by and large international law and its appliers black-box the preference formation within states or international organizations.

Examples of how NSAs have influenced state preferences are not hard to come by: just think of the outlawing of the slave trade in the 19th century, the creation of the International Criminal Court, or the adoption of conventions on landmines and cluster munitions. Article 71 of the UN Charter has even been explicitly adopted to enable NGOs to impact on the policy-setting and norm-setting process within the UN. Notably international relations scholars adhering to the constructivist school have well theorized such norm cascades, consisting of local NGOs teaming up with international NGOs so as to convince states or organizations to espouse civil society values and/or bring pressure to bear on recalcitrant states. ${ }^{24}$

\footnotetext{
19 The term 'participants' is also used by Higgins (1994) and D'Aspremont (2011).

20 Jessup (1956).

21 Willetts (2010), pp. 144 et seq.

22 Raustiala (2012). I use the term 'game', drawing on game theory, an epistemic field that studies conflict and cooperation between intelligent rational decision-makers and that has namely been influential in economics. Public international lawyers, especially in the United States, have recently relied on game theory to explain the workings of international law. See, e.g., Posner (2010). This is obviously not to say that the NSAs themselves consider their action to be a game.

23 ICJ, Legality of the Threat or Use of Nuclear Weapons, Advisory Opinion, ICJ Reports 1996, p. 226, Separate Opinion of Judge Guillaume, para. 2; ibid., Dissenting Opinion of Judge Oda, para. 8.

24 Finnemore and Sikkink (1998).
} 
Whether NSAs can also play one-level games in international law-making and policy-making is a different matter. Still, as a matter of positive law, it is hard to deny the role played by employers' and workers' associations in the International Labour Organization, ${ }^{25}$ the treaty-making practice of the Holy See ${ }^{26}$ or the legal value of International Committee of the Red Cross (ICRC) agreements concluded with states. $^{27}$ It is a more controversial proposition, however, that agreements concluded by armed opposition groups and states ${ }^{28}$ are governed by international law, that the practice of NSAs counts towards the formation of customary international law, ${ }^{29}$ or that transnational private regulation, ${ }^{30}$ or multi-stakeholder initiatives $^{31}$ can give rise to international obligations properly speaking. It is doubtful whether we should allow NSAs to play even more one-level games, e.g., whether one should invite NGOs to the international negotiation table. Practical problems and concerns over legitimacy militate against enhancing the law-making capacities of NSAs.

NSAs have not only participated in international law-making games but have also contributed or, more accurately, been allowed to contribute to monitoring compliance with international law. NSA compliance-monitoring can be formale.g. when it is provided for in a treaty or when NGO representatives form part of a compliance or inspection committee-or informal, when NGOs simply name and shame governments, armed groups, or corporations. It has a vertical dimension where NGOs monitor state compliance and a horizontal one where NSAs monitor other NSAs' compliance without state mediation. The latter dimension is surely innovative. The efforts of Geneva Call can be mentioned in this respect, ${ }^{32}$ as can the role of NGOs in auditing corporations' human rights record. Consumer and investor pressure, e.g., the divestment regarding the fossil fuel industry, ${ }^{33}$ shows how market forces can also enforce compliance with public values. ${ }^{34}$ The operation of the market diminishes the role of the state in compliance-monitoring, as individuals no

\footnotetext{
25 International Labour Office, Note on the role of employers' and workers' organizations in the implementation of ILO Conventions and Recommendations, 1987.

26 Ryngaert (2011).

27 Debuf (2015), pp. 327-329.

28 See, e.g., the agreement concluded between the Salvadorian Government and the Frente Farabundo Marti para la Liberatión National (FMLN), generally referred to as the San José Agreement on human rights, in which the FMLN agreed to comply with Common Art. 3 and Protocol II of the Geneva Conventions; the Humanitarian Agreement between the Government of Colombia and the Revolutionary Armed Forces of Colombia-People's Army (FARC-EP), concluded on 2 June 2001; the Agreement between the Government of the Republic of Sudan and the Sudan People's Liberation Movement (SPLM) to Protect Non-Combatant Civilians and Civilian Facilities from Military Attack, of 10 March 2002.

29 The ICRC believes, in any event, that it does not. See Henckaerts et al. (2005).

30 Cafaggi (2016).

31 See, e.g., the Kimberley Process Certification Scheme, an initiative involving states, industry, and civil society which 'imposes extensive requirements on its members to enable them to certify shipments of rough diamonds as "conflict-free" and prevent conflict diamonds from entering the legitimate trade'. See https://www.kimberleyprocess.com/en/about, visited July 2016.

32 See http://www.genevacall.org, visited June 2016.

33 See http://gofossilfree.org/what-is-fossil-fuel-divestment/, visited June 2016.

34 See also Gal-Or et al. (2015).
} 
longer need to cast a ballot when they want politics to change; they can simply vote with their shopping trolley or through their shareholder activism.

As far as NSA participation in dispute-settlement mechanisms is concerned, the picture somewhat resembles the games played in law-making. Without the pressure of discrete NSAs, some state-to-state contentious proceedings would not have been brought, e.g., the Whaling case before the ICJ, ${ }^{35}$ or, in the case of the World Trade Organization (WTO) Dispute Settlement Mechanism, the majority of cases would not have taken place. ${ }^{36}$ This is a two-level game, with states running errands for influential NSAs. In contrast, opportunities for direct intervention by NSAs in pending international law disputes are somewhat more circumscribed. The ICJ does not allow such intervention, although, in advisory proceedings, states can refer to written documents and statements submitted by NSAs to the Court. ${ }^{37}$ Trade and investment tribunals, as well as domestic courts in some jurisdictions, may for their part allow NGOs to file amicus curiae briefs in limited circumstances. ${ }^{38}$ A major breakthrough in international law is obviously the creation of direct access rights for NSA in some areas of international law-notably human rights and investment law-which makes them no longer dependent on the mechanism of diplomatic protection. Sometimes, states are also willing to conclude an arbitration agreement with NSAs. ${ }^{39}$ Furthermore, as these days international law issues are being litigated much more frequently in domestic courts, it is worth mentioning that NSAs concerned about international issues may in some national jurisdictions have standing to initiate proceedings single-handedly. For instance, in 2015, Dutch NGO Urgenda successfully brought a case before a Dutch court against the Dutch Government for failing to meet its international obligations to sufficiently reduce greenhouse gas emissions. ${ }^{40}$ Also in 2015, the Polisario Front, a national liberation movement fighting for the self-determination of the Sahrawi people in the Western Sahara, was granted standing before the Court of Justice of the European Union

\footnotetext{
35 ICJ, Whaling in the Antarctic (Australia v. Japan: New Zealand intervening), Merits, ICJ Reports 2014, p. 226. This case was brought by Australia against Japan partly as a result of pressure by environmentalists. See 'International Court of Justice orders Japan to End Antarctic Whaling', Sydney Morning Herald, 2 April 2014 (citing the backing of a legal solution by conservation groups including the International Fund for Animal Welfare, since 2005).

36 Businesses which are affected by a foreign state's trade restrictions have no other way than to lobby their government to bring a case. This state of affairs has led to calls to give direct effect to WTO obligations; this would allow the affected economic actors to bring a case, based on WTO law, in a domestic legal order. See Ruiz Fabri (2014). See for that matter on the role of business pressure to create the WTO in the first place: Aaronson (1996), p. 150 (writing that the Alliance for GATT NOW, which was in existence during the Uruguay Round 1986-1994, had a membership of more than 200,000 small and large businesses).

37 ICJ Practice Direction XII, http://www.icj-cij.org/documents/index.php?p1=4\&p2=4\&p3=0, visited June 2016.

38 On amicus curiae briefs before the WTO see http://www.wto.org/english/tratop_e/dispu_e/disp_ settlement_cbt_e/c9s3p1_e.htm, visited June 2016. On amicus curiae briefs before international investment tribunals see, e.g., Levine (2011).

39 See, e.g., Arbitration Agreement between the Government of Sudan and the Sudan People's Liberation Movement/Army on Delimiting Abyei Area, available at http://www.archive.pca-cpa.org/showpagefb0a. html?pag_id=1306, visited June 2016.

40 See http://www.urgenda.nl/en/, visited June 2016.
} 
(EU) and successfully argued that an EU-Morocco free trade agreement violated the right to self-determination of the Sahrawi people. ${ }^{41}$

\section{Obligations and Responsibility of Non-State Actors}

In the previous section, we discussed the (participatory) rights of NSAs in lawmaking, compliance-monitoring, and dispute-settlement. An NSA's international legal personality is however also a function of the NSA bearing international obligations, and having its international responsibility engaged. It should be emphasized that this 'debit side' of legal personality does not necessarily correlate with the 'credit side' of participatory rights; an NSA could well incur obligations under a norm of international law, even if it has not participated in the formation of that norm. ${ }^{42}$ Whether NSAs incur obligations under international law is, just like with rights, a matter of construing the relevant international norm, typically made by states. $^{43}$ Accordingly, there is no general theory on NSA international obligations; their scope and extent depend on the specific regime and the actor in question.

Direct NSA obligations exist, but they are certainly not widespread. They exist for armed groups under humanitarian law treaties ${ }^{44}$ and for deep seabed mining corporations under the UN Convention on the Law of the Sea. ${ }^{45}$ More often than not, NSA obligations are just indirect: the treaty imposes obligations on states to regulate NSAs. ${ }^{46}$ Such NSA obligations then arise under domestic rather than international law. A normative or political question is whether extending such obligations is desirable. As is known, a major debate has been going on regarding whether corporations incur, or rather should incur, obligations under international human rights law, with the Guiding Principles on Business and Human Rights

\footnotetext{
${ }^{41}$ See Case T-512/12 Front populaire pour la libération de la saguia-el-hamra et du rio de oro (Front Polisario) v. Council of the European Union, Judgment of 10 December 2015 (not yet published).

42 Although the absence of participation may create legitimacy/ownership/effectiveness problems. See Ryngaert (2010). This absence of participation in law-making and the attendant compliance problems have led Geneva Call to solicit unilateral acts from armed non-state actors in which they pledge to respect certain rules of international humanitarian law.

43 Kjeldgaard-Pedersen (2012).

44 Common Art. 3, Geneva Convention for the Amelioration of the Condition of the Wounded and Sick in Armed Forces in the Field (First Geneva Convention), Geneva Convention for the Amelioration of the Condition of Wounded, Sick and Shipwrecked Members of Armed Forces at Sea (Second Geneva Convention), Geneva Convention Relative to the Treatment of Prisoners of War (Third Geneva Convention), Geneva Convention Relative to the Protection of Civilian Persons in Time of War (Fourth Geneva Convention), 12 August 1949, 75 UNTS 287; Protocol Additional to the Geneva Conventions of 12 August 1949, and relating to the Protection of Victims of International Armed Conflicts (Protocol I), 8 June 1977, 1125 UNTS 3.

45 Art. 137 United Nations Convention on the Law of the Sea, 833 UNTS 3; [1994] ATS 31; 21 ILM 1261 (1982). See also Seabed Disputes Chamber of the International Tribunal for the Law of the Sea, Responsibilities and Obligations of States Sponsoring Persons and Entities with Respect to Activities in the Area, Advisory Opinion, 1 February 2011.

46 See, e.g., United Nations Convention against Corruption 2003, 2349 UNTS 41 (No. 42146); ILM (2004).
} 
having settled the matter for non-legal duties. ${ }^{47}$ A similar debate is going on regarding the human rights obligations of armed groups, although some scholars claim that such obligations already exist as a matter of positive international law. ${ }^{48}$

Once obligations have been established, the subsequent question is whether NSAs' international responsibility can be engaged for violations of international law. In early discussions within the NSA Committee of the International Law Association, some members suggested to draw up draft articles along the lines of the International Law Commission's (ILC) Articles on the Responsibility of States and International Organizations for Internationally Wrongful Acts. However, this idea was abandoned because of the limited primary obligations of NSAs, the sheer absence of relevant practice on responsibility, and the heterogeneity of the actors involved. Aspects of responsibility - in particular attribution and reparations-have so far mainly been theorized with respect to armed groups, e.g., can a terrorist act of an Islamic State (IS) sympathizer be attributed to IS or is the FARC under an obligation to make reparations to victims of its wrongful acts? ${ }^{49}$

\section{Where Does This Leave the State?}

The current legal landscape shows an empowerment of NSAs, a heteroglossian reality, but where does it leave the initial hero in the story: the state? In fact, from an international law perspective, the state can hardly be said to disappear. Firstly, NSA rights and obligations under international law do not emerge ex nihilo; they are granted by states, in their capacity as the quasi-exclusive law-makers in international law. Second, the scope of states' own obligations and rights is expanding rather than contracting. The state has increased due diligence obligations to ensure that NSAs over which it can exercise influence (e.g. corporations) comply with international law-as the Guiding Principles have reminded us. ${ }^{50}$ Also, the classic principles of the attribution of private acts to the state continue to apply. ${ }^{51}$ And to counter the threat posed by undesirable NSAs, states have carved out a legal space to exercise self-defence not just against states but also against the NSAs themselves, insofar as these have found a safe haven on another state's territory. ${ }^{52}$ Similarly, states have pushed the boundaries of international humanitarian law to justify the targeted killings of terrorist NSAs in a seemingly eternal war on terror. ${ }^{53}$

\footnotetext{
47 See United Nations Guiding Principles on Business and Human Rights: Implementing the United Nations 'Protect, Respect and Remedy' Framework, UN Doc. A/HRC/17/31 (2011).

48 Fortin (2017, forthcoming).

49 See for a discussion the contributions on armed groups in Gal-Or et al. (2015).

50 See United Nations Guiding Principles on Business and Human Rights: Implementing the United Nations 'Protect, Respect and Remedy' Framework, supra n. 47.

51 Arts. 5-11 Draft Articles on Responsibility of States for Internationally Wrongful Acts, November 2001, Supplement No. 10 (A/56/10); Ryngaert (2015). It can even be argued that the threshold of application of a number of attribution principles may have to be lowered, e.g., the effective control standard in respect of terrorist offences. See Trapp (2015).

52 See, e.g., Szabó (2011), pp. 203-248.

53 See, e.g., with respect to the United States and Israel, Blum and Heymann (2010).
} 
From an international governance perspective, the state has similarly not disappeared, but rather it has repurposed itself. ${ }^{54}$ The state may have abandoned command and control regulation and may satisfy itself with orchestrating and facilitating private initiative. ${ }^{55}$ For instance, states could support private, corporate grievance mechanisms by setting minimum standards to be met, and to provide a safety net when the private mechanism fails to deliver. This repurposing of the state also plays out at the purely domestic level, e.g., in the Netherlands, where the 'participation society' has replaced the welfare state; for obvious financial reasons, the state expects its citizens to care for themselves and their surroundings, while offering enabling incentives. ${ }^{56}$ Ultimately, how much state and non-state governance we want is a political question; a smart mix of both may be desirable.

Let me finally flag that some autocratic jurisdictions do not seem to opt for such an orderly retreat or repurposing of the state. Instead, they maintain, or even strengthen their totalitarian ambitions. ${ }^{57}$ Also in multilateral settings, emerging powers emphasize traditional principles of state sovereignty and non-intervention, and they are wary of empowering civil society. ${ }^{58}$

\section{Concluding Observations}

I have shown in this brief article that the participation of NSAs in global governance is a heteroglossian reality, even if the presence of the state continues to loom large. International law or, more accurately, the community of states has responded in a piecemeal fashion to this reality by conferring certain rights and obligations on categories of NSAs. Whether this has been done adequately is a different question altogether. I would venture to say that we do not need a world-scale theory to make sense of the international legal personality of the generic category of 'the non-state actor'. Rather, a functionally differentiated legal regime tailored to the specific actor and its activities is called for. Scholars may want to inquire whether the current and envisaged regimes are sufficiently guided by the principles of legitimacy, accountability, transparency, and effectiveness. Modesty is in the end also called for. As international lawyers, we may have to resist the temptation to cast all international social relationships in public international law terms or even in legal terms to begin with. We should not exclude the possibility that transnational regimes may function effectively via domestic regulation, non-state multistakeholder regulation, or without any regulation whatsoever. However, where these alternative regulatory solutions do not deliver, international law may well be the default option.

\footnotetext{
54 See Sassen (2006).

55 E.g., Abbott et al. (2015).

56 Delsen (2012).

57 See as regards Russia, e.g., Zimmerman (2014).

58 See, e.g., Sceats and Breslin (2012).
} 
Open Access This article is distributed under the terms of the Creative Commons Attribution 4.0 International License (http://creativecommons.org/licenses/by/4.0/), which permits unrestricted use, distribution, and reproduction in any medium, provided you give appropriate credit to the original author(s) and the source, provide a link to the Creative Commons license, and indicate if changes were made.

\section{References}

Aaronson SA (1996) Trade and the American dream: a social history of postwar trade policy. University Press of Kentucky, Lexington

Abbott KW et al (eds) (2015) International organizations as orchestrators. Cambridge University Press, Cambridge

Alston P (ed) (2005) Non-state actors and human rights, vol 9. Oxford University Press, Oxford

Anderson K (2010) Accountability as legitimacy global governance, global civil society and the United Nations. Brooklyn J Int Law 36:841-890

Bakhtin MM (1981) Epic and novel. In: Holquist M (ed) The dialogic imagination: four essays by Mikhail Bakhtin. University of Texas Press, Austin, pp 3-40 (original work published in 1941)

Blum G, Heymann PB (2010) Law and policy of targeted killing. Harvard National Security Journal $1: 145-170$

Branch J (2013) The cartographic state: maps, territory, and the origins of sovereignty. Cambridge University Press, Cambridge

Cafaggi F (2016) Transnational private regulation: regulating private regulators. In: Cassese S (ed) Research handbook on global administrative law. Edward Elgar, Cheltenham, pp 212-241

Charnovitz S (1996) Two centuries of participation: NGOs and international governance. Mich J Int Law 18:183-286

Cockburn P (2015) The rise of Islamic State: ISIS and the new Sunni revolution. Verso Books, London

Cumming LS (2010) GONGOs. In: Anheier H, Toepler S (eds) International encyclopedia of civil society. Springer, New York, pp 779-783

D'Aspremont J (ed) (2011) Participants in the international legal system: multiple perspectives on nonstate actors in international law. Routledge, London

Debuf E (2015) Tools to do the job: the ICRC's legal status, privileges and immunities. Int Rev Red Cross 97:319-344

Delsen L (2012) From welfare state to participation society. Welfare state reform in The Netherlands: 2003-2010. NiCE working paper 12-103. Nijmegen Center for Economics (NiCE) Institute for Management Research Radboud University Nijmegen

Dickens CJH (1859) A tale of two cities, vol 1. Clapman \& Hall, London

Finnemore M, Sikkink K (1998) International norm dynamics and political change. Int Organ 52:887-917

Ford RT (1999) Law's territory (a history of jurisdiction). Mich Law Rev 97:843-930

Fortin KMA (2017) The accountability of armed groups under human rights law. Oxford University Press, Oxford (forthcoming)

Gal-Or N, Ryngaert C, Noortmann M (eds) (2015) Responsibilities of the non-state actor in armed conflict and the market place: theoretical considerations and empirical findings. Brill Nijhoff, Leiden

Henckaerts J-M, Doswald-Beck L, Alvermann C (2005) Customary international humanitarian law, vol 1. Cambridge University Press, Cambridge

Higgins R (1994) Problems and process: international law and how we use it. Oxford University Press, Oxford

Jessup PC (1956) Transnational law. Tale University Press, Yale

Kjeldgaard-Pedersen A (2012) Personality and the separation of legal orders: the individual as the ultimate subject of international law. PhD thesis, Aarhus University

Lasswell HD, McDougal MS (1992) Jurisprudence for a free society: studies in law, science and policy, vol 1. Martinus Nijhoff Publishers, Leiden

Levine E (2011) Amicus curiae in international investment arbitration: the implications of an increase in third-party participation. Berkeley J Int Law 29:200-224

Martinez J (2013) The anti-slavery movement and the rise of non-government organizations. In: Shelton D (ed) The Oxford handbook of international human rights law. Oxford University Press, Oxford, pp 222-249 
Orakhelashvili A (2006) The idea of European international law. EJIL 17:315-347

Posner E (ed) (2010) Economics of public international law. Edward Elgar, Cheltenham

Raustiala K (2012) NGOs in international treaty-making. In: Hollis DB (ed) The Oxford guide to treaties. Oxford University Press, Oxford, pp 150-174

Robins N (2012) The corporation that changed the world: how the East India Company shaped the modern multinational, 2nd edn. Pluto Press, London

Ruggie JG (1993) Territoriality and beyond: problematizing modernity in international relations. Int Organ 47:139-174

Ruiz Fabri H (2014) Is there a case-legally and politically_for direct effect of WTO obligations. EJIL 25:151-173

Ryngaert C (2010) Imposing international duties on non-state actors and the legitimacy of international law. In: Noortmann M, Ryngaert C (eds) Non-state actor dynamics in international law: from lawtakers to law-makers. Ashgate, Aldershot, pp 69-90

Ryngaert C (2011) The legal status of the Holy See. Göttingen J Int Law 3:829-860

Ryngaert C (2015) State responsibility and non-state actors. In: Noortmann M, Reinisch A, Ryngaert C (eds) Non-state actors in international law. Hart Publishing, Oxford, pp 163-182

Sassen S (2006) Territory, authority, rights: from medieval to global assemblages, vol 7. Princeton University Press, Princeton

Sceats S, Breslin S (2012) China and the international human rights system. Chatham House, London

Szabó KT (2011) Anticipatory action in self-defence: essence and limits under international law. T.M.C Asser Press, The Hague

Trapp KN (2015) Shared responsibility and non-state terrorist actors. Neth Int Law Rev 63:141-160

Valverde M (2015) Chronotopes of law: jurisdiction, scale and governance. Routledge, London

Willetts P (2010) Non-governmental organizations in world politics: the construction of global governance. Routledge, London

Zimmerman W (2014) Ruling Russia: authoritarianism from the Revolution to Putin. Princeton University Press, Princeton 